\title{
THE EFFECT OF CENTRAL BANK INDEPENDENCE ON PRICE STABILITY: THE CASE OF INDONESIA
}

\author{
Yessy Andriani, SE, MIDEC \\ Prof. Prasanna Gai
}

\begin{abstract}
This paper investigates the relationship between central bank independence (CBI) and inflation in Indonesia during 1970-2006. Using partial adjustment Ordinary Least Square (OLS) and Engel Granger Error Correction Model, the result shows that legal CBI index inversely affect the inflation, while the turnover of governor is not significant. This result emphasizes Bank Indonesia to strengthen its independency in order to achieve his inflation target.
\end{abstract}

Keywords: Central bank independency, Inflation, Error Correction Model.

JEL Classification : C32, E58.

1 Author is lecture at Faculty of Economics, Andalas University and Professor of International Economics at Crawford School at Australian National University (ANU) Australia. 


\section{PENDAHULUAN}

Indonesia merasakan dampak yang besar oleh krisis ekonomi Asia yang tahun 1997. Saat itu Indonesia mengalami masalah ekonomi multi dimenasi termasuk defisit neraca berjalan yang cukup besar dan depresiasi nilai tukar. Meningkatnya ketidakpastian menyebabkan arus modal keluar, diikuti dengan masalah likuiditas di banyak bank. Sebagai lender of last resort, Bank Indonesia menyediakan pinjaman likuiditas untuk bank, namun, hal ini menyebabkan peningkatan suplai uang dan memacu hiperinflasi.

Salah satu faktor pendukung terjadinya krisis di tahun 1997 adalah karena bank sentral tidak independen. Saat rezim politik sebelumnya (Orde Lama), bank sentral selalu membiayai defisit budget pemerintah dengan mencetak uang. Pada rezim yang baru (Orde Baru), bank sentral diberikan mandat oleh pemerintah untuk mendukung tujuan pemerintah untuk selalu mendorong pertumbuhan ekonomi dan mengurangi pengangguran. Oleh karenanya, Bank Indonesia kesulitan untuk mengendalikan stabilitas harga yang menjadi tujuan utamanya. Hingga kemudian pada tahun 1999, Bank Indonesia menjadi benar-benar independen secara legal, bersamaan dengan tingginya kesadaran serta bukti teoritis dan empiris bahwa bank sentral yang independen harus mampu menjaga stabilitas harga. Hal ini juga merupakan rekomendasi dari IMF untuk pemulihan ekonomi pasca krisis. Melalui UU No. 23/1999, tanggung jawab bank sentral telah berfokus pada satu tujuan utama yaitu menjaga stabilitas harga, dimana sebelumnya bank sentral harus berfokus pada beberapa tujuan.

Teori dasar mengenai independensi bank sentral adalah teori bias inflasi. Bias inflasi menggambarkan ketidakstabilan harga yang akan menentukan harga dasar dari seluruh aktifitas ekonomi. Hal ini akan mempengaruhi ekonomi melalui daya beli dari mata uang nasional. Dengan harga yang tidak stabil, masyarakat cenderung tidak yakin dengan nilai sesungguhnya dari uang mereka yang telah terpotong oleh inflasi. Selain itu, harga yang tidak stabil akan meningkatkan ketidakpastian dan menciptakan ketidakstabilan ekonomi.

Salah satu langkah untuk mengatasi dilemma diatas adalah dengan memilih dan mengangkat bank sentral yang konservatif. Akan tetapi, penunjukan bank sentral yang konservatif ini masih menjadi perdebatan dikarenakan banyak penelitian yang menemukan hasil yang berbeda. Beberapa peneliti mengatakan bahwa independensi bank sentral dapat menciptakan inflasi yang rendah, sedangkan yang lainnya menemukan bahwa tidak ada korelasi antara Central Bank Independence (CBI) dan inflasi. Pada umumnya, korelasi negatif antara index CBI legal dan inflasi ditemukan pada negara-negara industri dimana hal ini tidak signifikan pada negara-negara berkembang. Di sisi lain, pergantian gubernur bank sentral sebagai indikator informal CBI umumnya berkorelasi positif terhadap inflasi pada negara-negara berkembang tapi tidak signifikan pada negara-negara industri atau negara maju.

Tujuan penelitian ini adalah untuk mengamati hubungan antara CBI dan inflasi di Indonesia dengan menggunakan data tahunan dari 1970 hingga 2006. Penelitian ini menggunakan dua indikator CBI; indeks legal dan TOR yang dibuat oleh Cukierman, Webb, dan Neyapty 
(CWN) (1995). Kami menggunakan dua pendekatan model; Ordinary Least Square (OLS) dengan menggunakan partial adjustment model dan Engel Granger Error Correction Model (EGECM) untuk mengidentifikasi dampak dari CBI terhadap inflasi, dan untuk menginvestigasi keseimbangan jangka panjang inflasi.

Bagian selanjutnya dari paper ini akan menguraikan teori danpenelitian empiris tentang dampak independensi bank sentral terhadap stabilitas harga. Bagian ketiga membahas data dan teknik estimasi yang digunakan, sementara bagian keempat menguraikan hasil estimasi dan analisisnya. Sesi terakhir adalah kesimpulan dan implikasi kebijakan, dan menjadi bagian penutup dari paper ini.

\section{TEORI}

\subsection{Model Dasar Independensi Bank Sentral}

Bias inflasi terjadi pada kebijakan moneter yang bersifat diskresi dan salah satu kemungkinan penyebab utamanya adalah bank sentral dikendalikan atau paling tidak diintervensi oleh pemerintah. Dengan kondisi tersebut,jika bank sentral mengetahui ekspektasi publik, maka bank sentral cenderung akan menciptakan kejutan inflasi untuk meningkatkan pendapatan seignorage dan mendorong aktifitas ekonomi riil. Inflasi akan lebih tinggi dari seharusnya dikarenakan inflasi tersebut adalah fungsi dari ekspektasi inflasi. Dalam hal ini, bank sentral cenderung tidak kredibel, dan akan lebih sulit untuk mengendalikan inflasi.

Ada tiga alasan mengapa bank sentral harus independen; pertama, teori pilihan publik menjelaskan bahwa bank sentral mendapatkan tekanan politik dari pemerintah untuk membiayai defisit anggaran pemerintah melalui kebijakan uang yang cenderung longgar (Eijffinger, 1997). Kedua, saat otoritas fiskal dominan, otoritas moneter tidak akan bisa untuk mengendalikan defisit anggaran pemerintah, sehingga penawaran uang menjadi bersifat endogen. Hal ini dimungkinkan saat bank sentral tidak independen (Sargent and Wallace, 1981 dikutip dari Eijffinger, 1997). Ketiga, terdapat masalah 'ketidak konsistenan waktu' atau time inconsistency saat kebijakan tersebut tidak lagi optimal untuk merespon rencana yang sebenarnya (Kydland dan Prescott, 1977; Barro dan Gordon, 1983; Rogoff, 1985).

Sebagaimana dijelaskan sebelumnya, salah satu solusi dalam mengatasi bias inflasi adalah memilih bank sentral yang independen dan konservatif, (Rogoff, 1985; Barro dan Gordon, 1984; Walsh, 2003). Bank sentral menjadi independen saat bebas dari tekanan politik atau intervensi pemerintah, termasuk bebas dari ambisi pemerintah untuk meningkatkan seignorage yang dilakukan dengan cara meningkatkan penawaran uang (Alesina dan Summers, 1993). Lebih lanjut, bank sentral yang independen seharusnya hanya memiliki satu tujuan, yakni stabilitas harga, yang mengimplikasikan bahwa bank sentral lebih berfokus pada inflasi dibandingkan pertumbuhan output. Dengan kondisi ini, Bank sentral dapat menyusun kebijakan moneter untuk mewujudkan stabilitas harga, bebas dari intervensi politik apapun (Ahsan, 2006; Pollard, 1993). 
Bank sentral juga tidak diperbolehkan untuk membeli obligasi pemerintah pada pasar primer, yang berarti tidak ada ruang bagi pemerintah untuk meminjam langsung dari bank sentral. Dengan ketentuan ini, pemerintah harus memilih kerangka kebijakan lain seperti meningkatkan pajak, menerbitkan surat hutang, atau melakukan pinjaman kepada bank konvensional dalam membiayai pengeluarannya.

Sebelum meninjau berbagai macam hasil dari bukti empiris, studi ini menyajikan model dasar bias inflasi dan CBI. Kami menggunakan model Rogoff (1985) sebagai titik awal. Model ini membandingkan fungsi kerugian dari pilihan kebijakan moneter yang bersifat diskresi, dengan kebijakan moneter yang konservatif dan berdasarkan rule. Inflasi pada kebijakan moneter diskresi dianalisis oleh Barro dan Gordon (1983) dengan mengadopsi fungsi penawaran Lucas-Island.

$$
y_{t}=y n+a\left(\pi_{t}-\pi_{t}^{e}\right)+\varepsilon_{t}
$$

dimana $y_{t}$ adalah output; $y n$ adalah natural rate of output; $\mu_{\mathrm{t}}$ adalah inflasi; $\mu_{\mathrm{t}}^{e}$ adalah expected inflation; dan real $\varepsilon_{\mathrm{t}}$ shock.

Output dalam model ini adalah fungsi dari tenaga kerja dan kapital (ala Cobb Douglas). Saat inflasi aktual lebih besar dari ekspektasi inflasi, maka upah riil akan turun karena ekspektasi upah riil akan lebih rendah sehingga perusahaan akan menyerap tenaga kerja lebih banyak. Di sisi lain, saat inflasi aktual lebih kecil dari ekspektasinya, maka upah riil akan meningkat dan perusahaan cenderung mengurangi serapan tenaga kerja.

Pada kebijakan moneter yang bersifat diskresi, bank sentral meminimalkan fungsi social loss berikut:

$$
L=\frac{1}{2} \pi_{t}^{2}+\frac{\lambda}{2}\left(y_{t}-y n-k\right)^{2}
$$

di mana $\lambda$ adalah preferensi terhadap output, dan $k$ adalah konstanta. Parameter $k$ bersifat imperatif dalam model ini. Pada kebijakan moneter yang bersifat diskresi, dalam mencapai stabilisasi output dan target inflasi, maka bank sentral akan mengendalikan output dalam kisaran nilai $y n+k$, sedangkan inflasi akan berfluktuasi pada nilai nol.

Hubungan sederhana antara inflasi dan instrumen kebijakan yang digunakan oleh pembuat kebijakan diberikan sebagai berikut:

$$
\pi=\Delta m+v
$$

di mana $\Delta m$ adalah tingkat pertumbuhan penawaran uang (turunan pertama log nominal suplai uang), dan $v$ adalah velocity shock. Untuk menghasilkan $\Delta m$, model ini mengasumsikan bahwa ekspektasi inflasi bersifat given, supply shock $\left(\varepsilon_{t}\right)$ dapat diamati oleh bank sentral, meskipun tidak demikian untuk velocity shock $\left(v_{t}\right)$. Selain itu juga diasumsikan $\varepsilon_{t}$ dan $v_{t}$ tidak saling berkorelasi. 
Mulanya, sektor swasta akan menetapkan tingkat upah berdasarkan ekspektasi inflasi. Pihak swasta harus berkomitmen pada kontrak upah nominal sebelum bank sentral menetapkan tingkat pertumbuhan nominal uang beredar. Pada kebijakan moneter diskresi, bank sentral sangat memperhatikan output dan mencoba untuk mengurangi variasi output dengan memilih tingkat inflasi tertentu. Dalam hal ini, bank sentral dapat menciptakan inflasi yang berbeda dari ekspektasi pihak swasta.

Dampak kebijakan moneter yang bersifat diskresi terhadap tingkat inflasi, diperoleh dengan cara mensubtitusi persamaan (1) dan (3) ke dalam fungsi loss bank sentral (2), kemudian melakukan turunan pertama terhadap pertumbuhan uang beredar:

$$
\begin{aligned}
& V=\frac{1}{2} \lambda\left[a\left(\Delta m+v-\pi^{e}\right)+e-k\right]^{2}+\frac{1}{2}(\Delta m+v)^{2} \\
& 0=\lambda\left[a\left(\Delta m+-\pi^{e}\right)+e-k\right]+(\Delta m) \\
& \Delta m=\frac{a^{2} \lambda \pi^{e}+a \lambda(k-e)}{1+a^{2} \lambda}
\end{aligned}
$$

Persamaan (4) menunjukkan bahwa guncangan penawaran agregat akan terjadi ketika bank sentral meminimalkan variabilitas output $(\lambda)$ dalam kisaran target yang telah ditetapkan, dan ini pada akhirnya menyebabkan inflasi tinggi. Terdapat trade off antara inflasi dan variabilitas output $\lambda$; semakin besar upaya bank sentral untuk mengurangi variabilitas output, maka akan semakin tinggi inflasi yang akan terjadi $(\Delta m)$. Sektor swasta akan menggunakan persamaan ini dalam membentuk ekspektasi mereka. Dengan demikian, kebijakan yang optimal bergantung pada ekspektasi inflasi pihak swastatersebut. Ekspektasi inflasi terbentuk dari pengamatan guncangan penawaran agregat $\varepsilon$ sebagai berikut:

$$
\pi^{e}=E[\Delta m]=\frac{a^{2} \lambda \pi^{e}+a \lambda k}{1+a^{2} \lambda}
$$

$\pi^{e}=a \lambda k>0$, mensubtitusikannya pada persamaan (3) dan menggunakan (4) untuk mendapatkan tingkat keseimbangan inflasi pada kebijakan yang bersifat diskresi:

$$
\pi^{d}=\Delta m+v=a \lambda k-\left(\frac{a \lambda}{1+a^{2} \lambda}\right) e+v
$$

Persamaan (5) menunjukkan bahwa tingkat inflasi rata-rata positif kurang lebih akan bernilai $a \lambda k$. Determinan bias inflasi $(k)$ yang pertama adalah dampak uang beredar pada output $(a)$, dan kedua, bobot bank sentral untuk mewujudkan tujuan output $(\lambda)$. Saat sektor swasta dengan 
sempurna mampu mengantisipai tingkat yang ditargetkan ini, maka dampak terhadap output akan nihil.

Jika kebijakan moneter didelegasikan pada bank sentral yang independen atau konservatif, maka bank sentral akan memberikan bobot sebesar $(1+\delta)$ pada inflasi, dan inflasi akan menjadi:

$$
\pi^{d}(\delta)=\Delta m+v=\frac{a \lambda k}{1+\delta} a \lambda k-\left(\frac{a \lambda}{1+\delta+a^{2} \lambda}\right) e+v
$$

Persamaan ini mengimplikasikan bahwa bias inflasi akan lebih rendah dikarenakan $1+\delta>1$ atau $\delta>0$, dan hal ini cenderung mengurangi fungsi kerugian. Meskipun demikian, koefisien guncangan penawaran agregat $(\varepsilon)$ juga lebih rendah, mengimplikasikan bank sentral tidak cukup merespon guncangan penawaran agregat tersebut. Dengan kata lain, saat bank sentral lebih menekankan inflasi dibandingkan stabilitas output, maka bias inflasi akan lebih rendah, namun dengan stabilitas output yang lebih rendah. Berdasarkan hasil ini, banyak peneliti menyimpulkan bahwa inflasi rata-rata yang lebih rendah dapat dicapai dengan memilih bank sentral yang independen dan konservatif; namun dengan biaya stabilitas output yang lebih rendah.Ini penyebab mengapa trade-off antara rata-rata inflasi yang lebih rendah dengan tingginya variabilitas output dapat terjadi.

Berger, Haan, dan Eijffinger (2001) menggunakan persamaan sederhana lain untuk menjelaskan teori independensi bank sentral (lihat persamaan 7). Model ini menggunakan persamaan fungsi loss dan fungsi Lucas-Island yang sama, dan proses pembentukan ekspektasi inflasi yang rasional seperti pada model Barro dan Gordon. Untuk bank sentral yang menganut kebijakan yang bersifat diskresi, maka inflasi akan menjadi:

$$
\pi_{t}=\chi y_{t}^{*}-\frac{\chi}{\chi+1} \mu_{t}
$$

Suku pertama yang ada pada sisi kanan persamaan di atasadalah bias inflasi. Saat sebuah negara mengalami bias inflasi yang tinggi, maka hal ini mengimplikasikan bahwa pemerintah memberikan kejutan inflasi yang besar. Suku kedua adalah tingkat stabilisas guncangan output yang akan berdampak pada inflasi. Fungsi kerugian bank sentral yang bersifat diskresi adalah sebagai berikut:

$$
L^{c b}=\frac{1+\varepsilon}{2} \pi_{t}^{2}+\frac{\lambda}{2}\left(y_{t}-y_{t}^{*}\right)^{2}
$$

Pada sisi lain, saat bank sentral independen atau konservatif, maka inflasi akan menjadi: 


$$
\pi_{t}=\frac{\chi}{1+\gamma \varepsilon} y_{t}^{*}-\frac{\chi}{1+\gamma \varepsilon+\chi} \mu_{t}
$$

Perbandingan antara tingkat inflasi pada kebijakan yang diskresi pada persamaan (7) dengan bank sentral yang independen (konservatif) pada persamaan (9) menunjukkan bahwa inflasi dapat menjadi lebih rendah pada bank sentral yang independen dibandingkan kebijakan yang diskresi. Parameter penentunya adalah $\gamma$ dan $\varepsilon$. Saat keduanya bernilai positif, maka tingkat inflasi akan menjadi lebih rendah. Hal ini menunjukkan bahwa dengan mendelegasikan kebijakan moneter kepada bank sentral yang konservatif, maka akan menghasilkan nilai $\gamma$ dan $\varepsilon$ yang positif, sehingga inflasi menjadi lebih rendah. Sebaliknya, saat $\gamma$ dan $\varepsilon$ sama dengan nol, maka bank sentral akan memiliki preferensi yang sama dengabn preferensi pemerintah dalam hal pengurangan inflasi; dan ini mengimplikasikan bahwa independensi bank sentral tidak akan berpengaruh terhadap pencapaian tingkat inflasi yang lebih rendah. Hal ini sejalan dengan Eijffinger dan Hoebericht (1998):

$$
M_{t}=\gamma L^{c b}+(1-\gamma) L^{G}
$$

dimana $\gamma$ adalah tingkat CBI, dan karena $\gamma=1$, makabank sentral sepenuhnya independen.

Meskipun demikian, bank sentral yang konservatif sendiri tidak cukup untuk mencapai stabilitas harga dikarenakan kecilnya respon terhadap guncangan. Lohmann (1992) menyatakan bahwa menunjuk sendiri bank sentral untuk menghadapi inflasi merupakan ide yang bagus, tapi tidak berlaku saat guncangannya terlalu besar. Dengan cara ini, maka bank sentral tetap responsif terhadap stabilisas output. Walsh (1995) memberikan solusi alternatif untuk masalah bias inflasi yang dikenal sebagai 'Optimal Walsh Contracts'. la menyarankan bahwa ketimbang menunjuk bank sentral, lebih baik menyediakan bonus untuk bank sentral saat inflasi berhasil diturunkan. Pendekatan ini lebih kontraktual dibandingkan solusi institusional.

\subsection{Hasil Empiris}

Secara empiris, apakah tingginya tingkat CBI berhubungan dengan rendahnya inflasi, masih merupakan perdebatan kontroversial di antara para ekonom. Bukti empiris yang menunjukkan hubungan yang negatif antara tingkat CBI dan inflasi rata-rata ditemukan oleh Grilli dkk (1991), Cukierman et.al. (1992), Alesina dan Summer (1993), Berger (2000) Jacome (2007), Hayo dan Voigt (2005), Hicks (2004), Eijffinger dkk, (1998).

Korelasi antara CBI dan inflasi digambarkan pada Gambar 1. Swiss dan Jerman dengan tingkat $\mathrm{CB}$ yang tinggi memiliki tingkat inflasi yang rendah. Di Jepang, Kanda, dan Belanda, tingkat CBI sedangnya berhubungan dengan inflasi rata-rata. Demikian halnya dengan Selandia Baru dengan $\mathrm{CBI}$ yang rendah dengan tingkat inflasi yang rendah, atau sebaliknya. 


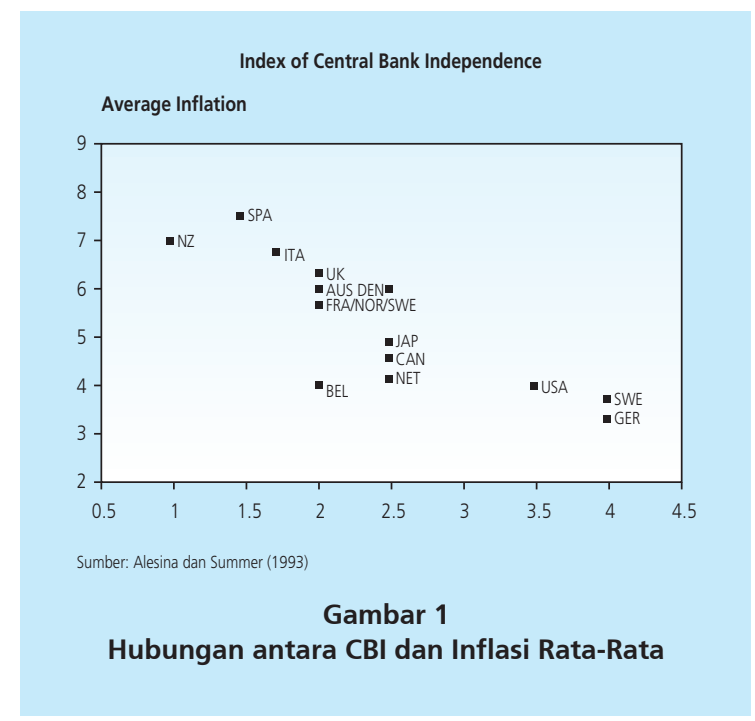

Meskipun demikian, Luna (2003) menyatakan bahwa tidak terdapat korelasi antara CBI dan inflasi. Dengan menggunakan data panel lintas negara pada 23 negara OECD, ia menyatakan bahwa inflasi yang rendah dapat dicapai tanpa mendelegasikan kebijakan moneter ke bank sentral yang independen. Inflasi yang rendah lebih berhubungan dengan target nilai tukar dibandingkan bank sentral yang konservatif. Dengan menggunakan reformasi institusional sebagai proksi untuk $C B$, ia menemukan bahwa stabilitas harga dicapai setelah implementasi reformasi independensi, hanya pada negara Spanyol, Yunani, Selandia Baru, Portugal, dan Italia.

Tidak seperti Luna, Jong (2002) melalui hasil penelitiannya menemukan korelasi negatif antara CBI dan inflasi pada negara-negara OECD. la menyatakan bahwa korelasi negatif ini terjadi dikarenakan faktor budaya dimana masyarakat tidak menyukai ketidakpastian. Korelasi yang tidak begitu jelas juga ditemukan oleh Campilo dan Miron (1996), namun dengan hasil yang tidak sama dengan temuan Luna (2003). Regresi panel antar negara yang mereka gunakan menunjukkan bahwa rezim nilai tukar tidak begitu berpengaruh untuk menentukan tingkat inflasi. Faktor yang paling penting adalah fundamental ekonomi seperti keterbukaan dan pajak yang optimal.

Pollard (1993) memiliki hasil yang sama akan tetapi ia menemukan bahwa bank sentral yang independen dapat meningkatkan konflik kebijakan dengan pemerintah karena mereka memiliki preferensi yang berbeda; dan jika hal ini terbukti, maka pertumbuhan ekonomi akan lebih lambat.

Para ekonom tidak hanya berfokus kepada apakah CBI akan menghasilkan stabilitas harga, tapi juga apakah memberikan respon terhadap kinerja ekonomi. Waud (1995) menyatakan 
bahwa $\mathrm{CBI}$ akan meningkatkan trade-off antara inflasi dan kinerja ekonomi seperti yang diasumsikan dalam kurva Philip. Bank sentral yang independen dapat menciptkan inflasi yang rendah dan juga pertumbuhan yang lambat. Namun demikian, Fisher (dikutip dari Eijffinger (1997)) mengemukakan bahwa trade-off hanya terjadi dalam jangka pendek. Pada jangka panjang, kurva Philip berbentuk vertikal, yang mengimplikasikan kebijakan moneter hanya akan mempengaruhi inflasi; sehingga tidak ada korelasi antara CBI dan output.

Hasil yang bervariasi tersebut dapat disebabkan oleh pengukuran CBI yang berbeda. Studi yang dilakukan oleh Bade dan Parkin (1988) mengukur hubungan antara bank sentral dan pemerintah sebagai 'anggaran'. Mereka membuat sebuah indeks berdasarkan hubungan institusional antara bank sentral dan pemerintah.

Grilli, Masciandaro, dan Tabellini (1991) menyajikan indeks berbeda yang dikenal sebagai Indeks GMT, berdasarkan pengukuran independensi politik dan ekonomi. Dengan menggunakan defisit pemerintah yang dibiayai oleh bank sentral, mereka menemukan korelasi negatif antara $\mathrm{CBI}$ dan inflasi.

Cukierman, Webb, dan Neyapti (1992) memperkenalkan indeks CWN. Mereka membagi pengukuran tersebut ke dalam dua kategori; indeks legal Independensi Bank Sentral (CBI) dan tingkat pergantian gubernur bank sentral (TOR). Indeks CBI legal berkorelasi negatif dan signifikan terhadap inflasi pada negara-negara maju, akan tetapi tidak signifikan pada negaranegara berkembang. TOR berkorelasi positif pada sebagian kecil negara maju akan tetapi tidak berkorelasi pada negara-negara industri.

Variasi pengukuran CBI yang digunakan pada banyak studi empiris telah memperjelas perbedaan hasil yang substantifdalam menjelaskan dampak CBI terhadap inflasi. Alesina dan Summer (19820 dan Jacome (2001, 2007) yang menggunakan ekspansi indeks GMT dan CWN menghasilkan korelasi negatif antara CBI dan inflasi. Panagiotidis (2006) menemukan hasil yang sama dengan menggunakan indeks CWN pada kasus Yunani.

Voig (2005) menggunakan tingkat de facto bank sentral sebagai pengukuran CBI dan menemukan korelasi negatif antara CBI dan inflasi. Akan tetapi, TOR yang merupakan proksi informal untuk CBI menyajikan korelasi yang positif.

Campilo dan Miron (1997) sebenarnya menemukan hasil yang sama seperti Cukierman (1992) akan tetapi dengan kesimpulan yang berbeda. Mereka mengatakan bahwa tidak ada korelasi antara CBI dan inflasi karena indeks CWN bernilai negatif dan signifikan hanya pada negara berpendapatan tinggi dan bernilai positif serta tidak signifikan pada negara-negara berkembang. Saat mereka menyatukan seluruh data secara bersamaan, hasilnya tidak jelas. Hal ini sejalan dengan studi Cukierman (1992) yang menemukan indeks tersebut hanya signifikan pada negara-negara maju.

Hal lain yang menjelaskan mengapa bukti empiris menyajikan hasil yang berbeda adalah perbedaan rezim nilai tukar. Negara dengan rezim nilai tukar tetap akan kehilangan 
independensinya; sebaliknya, dampak yang kuat dari CBI terhadap inflasi dapat ditemukan pada negara-negara dengan rezim nilai tukar yang floating (Cukierman, 2001).

Model empiris dan teknik estimasi adalah kemungkinan penyebab lain dari perbedaan hasil yang ada. Banyak studi sebelumnya yang menemukan terdapat korelasi positif atau tidak adanya korelasi antara CBI dan inflasi, dikarenakan mereka menggunakan metodologi ekonometrik yang tidak memperhitungkan kesalahan proksi yang digunakan. Akibatnya, hasilyang ditemukan bersifat spurious. Sebagai contoh, Campilo dan Miron (1997) dan Ismihan dan Ozkan (2004) mengestimasi inflasi langsung terhadap proksi CBI dengan menggunakan Ordinary Least Square (OLS) tanpa memperhitungkan error pada indeks CBI. Mereka menemukan bahwa tidak ada hubungan antara CBI dan inflasi.

Brum $(2002,2006)$ mengatakan bahwa masalah pada estimasi tersebut dapat diselesaikan melalui analisis strukturkovarian. Metode ini memperhitungkan error pada indeks CBI, sehingga estimasi akan menghasilkan penduga yang tidak bias. Bedasarkan bukti empiris, Brum (2002) menggunakan metode ini untuk mengestimasi model Campilo dan Morin (1997) dan Ismihan dan Ozkan (2003), dan menemukan bahwa CBI berkorelasi negatif dan signifikan dengan inflasi bahkan pada sampel negara-negara berkembang. Terakhir yang dapat disebutkan adalah Hikcs (2004) yang menggunakan proses ARIMA dan menemukan korelasi negatif antara CBI dan inflasi.

\section{METODOLOGI}

\subsection{Variabel dan Data}

Variabel dependen (inflasi) diproksi dengan Indeks Harga Konsumen (IHK). Variabel independen terdiri dari indeks legal independensi bank sentral (legal CBI), pergantian gubernur bank sentral (TOR), uang beredar (M1), nilai tukar (ER), dan lag IHK. Tiga yang disebutkan terakhir merupakan variabel kontrol. Data yang digunakan adalah data tahunan dari 1970 hingga 2006.

Tingkat inflasi diukur sebagai log persentase tahunan Indeks Harga Konsumen (IHK). Data IHK didapatkan dari International Financial Statistics (IFS) dari 17 ibu kota, mencakup periode tahun 1970 - 2006 dengan menggunakan tahun dasar 1993.

Indeks independensi mencakup rentang tingkat independensi rendah (mendekati nol) dan tinggi (mendekati satu). Dengan cara ini, penelitian ini mampu untuk mencakup seluruh data dari 1970 hingga 2006 tanpa harus membagi periode dalam dua kategori yakni sebelum dan sesudah dikeluarkannya UU tentang independensi (UU No. 23/1999).

$\begin{array}{lll}0.0 & & \text { (Scales) } \\ \text { Too dependence } & 0.5 & \text { Too independence }\end{array}$


Indeks legal independensi bank sentral untuk Indonesia dibentuk oleh Cukierman, Webb, dan Neyapty (Indeks CWN). Indeks ini diukur berdasarkan 16 karakteristik, dihasilkan dari hubungan antara Bank Indonesia dan pemerintah. Karakteristik tersebut dikategorikan ke dalam empat kelompok utama; pertama adalah Chief Executive Officer (CEO), terdiri dari proksi-proksi yang mencakup: masa periode pemerintahan, pemecatan gubernur bank sentral, siapa yang menunjuk gubernur, dan boleh tidaknya merangkap jabatan. Kedua adalah variabel formulasi kebijakan; terdiri dari proksi-proksi yang mencakup: siapa penyusun kebijakan, keterlibatan dalam keputusan akhir, dan tingkat partisipasi bank sentral dalam merumuskan budget pemerintah. Ketiga adalah variabel tujuan bank sentral, terdiri dari: apakah bank sentral memiliki satu target (stabilitas harga) ataukah berbagai tujuan (stabilitas harga, pertumbuhan, pengangguran). Keempat adalah batas pinjaman bank sentral kepada pemerintah; terdiri dari proksi-proksi yang mencakup: sekuritisasi pinjaman (advances and securities lending), kewenangan bank sentral dalam menentukan jatuh tempo pinjaman, potensi peminjaman dari bank sentral, jenis batasan pinjaman, jatuh tempo pinjaman, suku bunga pinjaman, dan pelarangan bagi bank sentral untuk membeli surat berharga pemerintah pada pasar primer.

Dengan menggunakan 16 variabel, indek CBI dihitung dengan metode skala, dengan nilai berkisar antara 0 (nol) dan 1 (satu)². Untuk periode 1970 hingga 1998, digunakan indeks yang dihitung oleh Cukierman, Webb, dan Neyapty (1996) untuk beberapa negara maju dan berkembang termasuk Indonesia. Indeks CBI legal dari 1999 hingga 2006 adalah data primer yang dikumpulkan melalui survei di Bank Indonesia. Rangkaian pertanyaan sama dengan indeks CWN.

Indikator lain yang digunakan dalam penelitian ini seperti pengukuran independensi pergantian gubernur bank sentral (TOR). CWN menyatakan bahwa pergantian gubernur bank sentral sebagai indikator informal untuk mengukur independensi. Pernyataan ini berdasarkan asumsi makin tingginya pergantian gubernur, makin tinggi kemungkinan akan ketergantungan bank sentral terhadap otoritas politik. Asumsi ini hanya terjadi di negara-negara berkembang, dan tidak pada negara-negara dengan stabilitas pemerintahan seperti Denmark dan Inggris (Cukierman, 1996).

Pergantian gubernur bank sentral (TOR) diukur berdasarkan rata-rata pergantian gubernur dalam beberapa tahun. Secara rinci, Cukierman (1995) menggunakan rumus sebagai berikut:

Average Annual Turnover of central bank governor

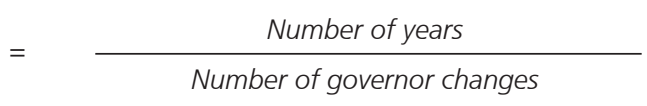

Number of governor changes

Nilai kritis dari rata-rata TOR tahunan berada pada kisaran 0.2 - 0.5. Jika siklus pemilihan kurang dari empat tahun, maka kemungkinan batas atasnya bisa lebih dari 0.5. Sebaliknya,ketika

2 Perhitungannya disediakan oleh penulis berdasarkan permintaan 
siklus pemilihannya lebih dari lima tahun, maka kemungkinan batas bawahnya akan lebih kecil dari 0.2. Untuk kasus Indonesia, batas tingkat pergantian sebelum tahun 1970 cenderung tidak stabil, sehingga berada pada kisaran 0 dan 0.6. Setelah tahun 1970, kisaran kritisnya berada di antara 0 dan 0.2 .

Variabel kontrol pertama yang digunakan pada penelitian ini adalah narrow money sebagai proksi untuk uang beredar. Variabel kontrol yang kedua adalah variabel nilai tukar yang diperkirakan juga memiliki korelasi yang signifikan terhadap inflasi. Data uang beredar dan dan nilai tukar didapatkan dari International Financial Statistics (IFS). Variabel lain adalah ekspektasi inflasi, yang diproksi dengan lag dari log IHK, yang diperkirakan memiliki korelasi positif dengan inflasi saat ini.

\subsection{Teknik Estimasi}

Langkah pertama yang dilakukan adalah mengidentifikasi korelasi antara dua indikator independensi bank sentral yang dimasukkan di dalam model, dengan menggunakan korelasi Spearman. Gujarati (1996) menyatakan bahwa seluruh variabel penjelas harus independen satu sama lain, sehingga memiliki korelasi yang rendah. Jika terdapat korelasi yang kuat, maka variabel tersebut tidak dapat digunakan sebagai variabel independen secara bersamaan.

Langkah berikutnya adalah mengestimasi persamaan tersebut dengan menggunakan Ordinary Least Square (OLS):

$$
P I=c+\alpha_{1} \operatorname{LegalCBI}+\alpha_{2} T O R+\alpha_{3} \log (m 1)+\alpha_{4} \log (e r)
$$

Panagiotidis (2005) mengukur transformasi inflasi terhadap indikator CBI (Legal CBI dan TOR) dan variabel dummy (yang menangkap perbedaan rezim seperti rezim Bretton Wood System, mekanisme nilai tukar fleksibel, dan Maastricht). Di sisi lain, studi ini mengestimasi inflasi pada kedua indikator CBI dan uang beredar serta nilai tukar sebagai variabel control.

Estimasi persamaan (10) dengan menggunakan OLS berpotensi menjadi estimasi yang spurious saat variabel yang terlibat memiliki unit root. Mengikuti Enders (2004), alternatifnya adalah menggunakan bentuk diferensiasi pertama. Untuk mengantisipasi masalah auto korelasi, kami menggunakan lag inflasi untuk melihat korelasinya pada perubahan inflasi sebelumnya terhadap perubahan inflasi saat ini. Lag inflasi secara teoritis rasional, dikarenakan kita dapat melihat hubungan antara ekspektasi inflasi dan inflasi.

Dengan pertimbangan dan argumentasi di atas, maka model empiris yang diestimasi adalah sebagai berikut:

$$
\begin{aligned}
d P I_{t}=c & +\alpha_{1} d(P I(-1))+\alpha_{2} d(\operatorname{LegalCBI})_{t}+\alpha_{3} d(\text { TOR })_{t} \\
& +\alpha_{4} d(\log (m 1))_{t}+\alpha_{5} d(\log (e r))_{t}+\varepsilon_{t}
\end{aligned}
$$


Berdasarkan Gujarati (1995) dan Wooldridge (2006), kita dapat menggunakan model ini sepanjang tidak terdapat masalah serial korelasi, heteroscedasticity dan multikolinearitas. Walaupun $d(P I(-1))$ bergantung pada $\varepsilon_{e-t}$ dan seluruh error periode sebelumnya, namun ia tidak berkorelasi dengan error periode sekarang $\left(\varepsilon_{t}\right)$. Dengan demikian, sepanjang $\varepsilon_{t}$ bersifat serially independent, maka $d(P I(-1))$ juga akan independen atau tidak berkorelasi dengan $\varepsilon_{t}$.

Model tersebut memenuhi asumsi OLS khususnya untuk 'tidak adanya' korelasi antara variabel penjelas dan stochastic disturbance term. Kami menguji masalah serial korelasi dengan Uji Godfrey-Breusch yang kemudian dikenal sebagai uji LM. Kami menggunakan uji white heteroscedasticity untuk masalah heteroscedasticity dan melihat uji korelasi untuk masalah multikolinearitas.

Uji stasioner pada error persamaan (12) penting untuk menemukan apakah variabelvariabel pada persamaan tersebut berkointegrasi, yang bermakna terdapat hubungan jangka panjang antar variabel dalam model, (Enders, 2004). Terdapat dua jenis ECM yang dapat kita gunakan; Engel Granger Error Correction Model (EGECM), dan Wickens-Breusch Error Correction Model, seperti dijelaskan di bawah ini.

Untuk metode Engel Granger ECM, pertama diestimasi residual error $\varepsilon_{t}=y_{t}-\alpha_{1}-\alpha_{2} x_{t}$ dan $\Delta \hat{\varepsilon}_{t}=\beta_{1} \hat{\varepsilon}_{t-1}$, kemudian ECM sederhana dirumuskan sebagai $\Delta y_{t}=\alpha_{1}+\alpha_{2} \Delta x_{t}+\alpha_{3} \hat{\varepsilon}_{t-1}+u_{t}$. Jika kita mengasumsikan Autoregressive Distributed Lag (1), maka:

$$
\begin{aligned}
& y_{t}=\alpha_{0}+\alpha_{1} y_{t-1}+\beta_{0} x_{t}+\beta_{1} x_{t-1}+\varepsilon_{t} \\
& y_{t}-y_{t-1}=\alpha_{0}+\alpha_{1} y_{t-1}-y_{t-1}+\beta_{0} x_{t}+\beta_{1} x_{t-1}+\varepsilon_{t} \\
& d y_{t}=\alpha_{0}+\left(\alpha_{1}-1\right) y_{t-1}+\beta_{0}\left(x_{t}-x_{t-1}\right)+\beta_{0} x_{t-1}+\beta_{1} x_{t-1}+\varepsilon_{t} \\
& d y_{t}=\alpha_{0}+\left(\alpha_{1}-1\right) y_{t-1}+\beta_{0} d x_{t}+\left(\beta_{0}+\beta_{1}\right) x_{t-1}+\varepsilon_{t} \\
& d y_{t}=\alpha_{0}+\beta_{0} d x_{t}-\left(\alpha_{1}-1\right)\left[y_{t-1}-\left(\frac{\beta_{0}+\beta_{1}}{\alpha_{1}-1}\right) x_{t-1}\right]+\varepsilon_{t} \\
& d y_{t}=\alpha_{0}+\beta_{0} d x_{t}-\lambda E C_{t-1}+\varepsilon_{t}
\end{aligned}
$$

Persamaan (13) adalah Engel Granger Error Correction Model, dimana - $\lambda E C_{t-1}$ merupakan error correction term dan $\lambda$ adalah parameter kecepatan penyesuaian. Makin besar nilai $\lambda$, makin besar penyesuaian deviasi sebelumnya terhadap keseimbangan jangka panjang; sebaliknya, rendahnya nilai $\lambda$ mengimplikasikan lambatnya penyesuaian jangka pendek untuk kembali 
pada kondisi ekuilibrium. Merujuk kepada prosedur di atas, kita dapat menentukan model Engel Granger empiris sebagai berikut:

$$
\begin{aligned}
d(P I)_{t}=\alpha_{0} & +\beta_{0} d(C B I)_{t}+\beta_{0} d(\text { TOR })_{t}+\beta_{1} d(\log (m 1))_{t}+\beta_{2} d(\log (e r))_{t} \\
& +\lambda E C_{t-1}+\varepsilon_{t}
\end{aligned}
$$

Spesifikasi model ECM yang kedua adalah Winkens-Breusch Error Correction Model. Model ini dapat menjelaskan hubungan jangka panjang antara variabel dependen dan independen, serta memberikan cara yang valid untuk menguji kesalahan spesifikasi model. Dari Persamaan(13b):

$$
\begin{aligned}
& y_{t}-y_{t-1}=\alpha_{0}+\alpha_{1} y_{t-1}-y_{t-1}+\beta_{0} x_{t}+\beta_{1} x_{t-1}+\varepsilon_{t} \\
& y_{t}-\alpha_{1} y_{t}=\alpha_{0}+\alpha_{1} y_{t-1}-\alpha_{1} y_{t}+\beta_{0} x_{t}-\beta_{1} x_{t}+\beta_{1} x_{t}+\beta_{1} x_{t-1}+\varepsilon_{t} \\
& \left.\left(1-\alpha_{1}\right) y_{t}=\alpha_{0}-\alpha_{1} d y_{t}+\left(\beta_{0}+\beta_{1}\right) x_{t}-\beta_{1} d x_{t}\right)+\varepsilon_{t} \\
& y_{t}=\frac{\alpha_{0}}{1-\alpha_{1}}-\frac{\alpha_{1}}{1-\alpha_{1}} d y_{t}+\frac{\beta_{0}+\beta_{1}}{1-\alpha_{1}} x_{t}-\frac{\beta_{1}}{1-\alpha_{1}} d x_{t}+\varepsilon_{t}
\end{aligned}
$$

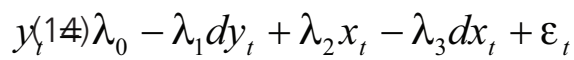

Menggunakan persamaan ini, maka model empiris Winkens-Breusch dirumuskan sebagai berikut:

$$
\begin{aligned}
P I_{t}= & \lambda_{0}+\lambda_{1} d(P I)_{t}+\lambda_{2} d(C B I)_{t}+\lambda_{3} d(T O R)_{t}+\lambda_{4} d(\log (m 1))_{t}+\lambda_{5} d(\log (e r))_{t} \\
& \lambda_{6}(C B I)_{t}+\lambda_{7}(\text { TOR })_{t}+\lambda_{8}(\log (m 1))_{t}+\lambda_{9}(\log (e r))_{t}+\varepsilon_{t}
\end{aligned}
$$

Kemungkinan terdapat masalah endogenitas pada model ini, dan untuk itu perlu untuk menggunakan Two Stage Least Square (TSLS), beserta serangkaian variabel instrument (IV).

\section{HASIL dan ANALISIS}

Hasil awal menunjukkan bahwa seluruh variabel (inflasi, indeks independensi bank sentral, pergantian gubernur, uang beredar, dan nilai tukar), bersifat stasioner pada turunan pertama. Residual pada model juga stasioner, yang membenarkan adanya kointegrasi antar variabel. 
Kami juga menguji korelasi antara legal indeks CBI dan TOR (pergantian gubernur bank sentral) dengan menggunakan uji korelasi Spearman. Hasilnya menunjukkan kedua indikator berkorelasi lemah (0.28).

Hasil estimasi disajikan berikutini. Model tersebut telah bebas dari masalah serial korelasi dengan Breusch-Godfrey Serial Correlation LM Test (F-Statistic $=0.632533$ dan $p=0.538934$ ). (lihat Tabel 3). Dengan menggunakan correlogram Q-statistics dan uji White, kami juga membenarkan bahwa model tersebut bebas dari masalah heteroscedasticity.

Sebagian besar dari variabel tersebut signifikan secara statistik pada tingkat 5 persen kecuali TOR dan lag inflasi. Nilai R2 mengindikasikan bahwa variasi variabel independen dapat menjelaskan 88.16 persen variasi variabel dependen.

\begin{tabular}{l|c|c|c|c}
\multicolumn{5}{c}{ Tabel 1 } \\
\multicolumn{1}{c|}{ Hasil Estimasi Model Standar } \\
\hline Variable & Coefficient & Std. Error & t-Statistic & Prob. \\
\hline C & -0.084955 & 0.027666 & -3.070776 & 0.0046 \\
D(PI(-1)) & -0.124883 & 0.080302 & -1.555153 & 0.1308 \\
D(CBI) & -0.844977 & 0.146587 & -5.764348 & 0.0000 \\
D(TOR) & 0.244953 & 0.207011 & 1.183286 & 0.2463 \\
D(LOG(M1)) & 0.255763 & 0.125883 & 2.031749 & 0.0514 \\
\multicolumn{1}{|c|}{ D(LOG(ER)) } & 0.524653 & 0.055112 & 9.519822 & 0.0000 \\
\hline R-squared & 0.881640 & Mean dependent var & & 0.000686 \\
Adjusted R-squared & 0.861233 & S.D. dependent var & & 0.188990 \\
S.E. of regression & 0.070402 & Akaike info criterion & -2.314395 \\
Sum squared resid & 0.143735 & Schwarz criterion & -2.047764 \\
Log likelihood & 46.50191 & F-statistic & 43.20299 \\
Durbin-Watson stat & 1.673317 & Prob(F-statistic) & 0.000000 \\
\hline Dependent Variable: D(PI) & & & \\
Note: Method Leass Square, 35 included observations from 1972 - 2006. &
\end{tabular}

Hasil estimasi menunjukkan bahwa independensi legal Bank Sentral (CBI) berhubungan terbalik dengan inflasi, yang pada umumnya terjadi pada negara-negara maju. Ini adalah temuan yang berlawanan; dimana umumnya korelasi antara CBI legal dan inflasi adalah negatif dan tidak signifikan pada negara-negara berkembang. Kami menemukan hasil yang sama saat menggunakan model Engel Granger Error Correction; keduanya mengindikasikan independensi bank sentral juga negatif dan tidak signifikan, dengan magnitude yang sama (0.78).

Koefisien negatif CBI menunjukkan makin rendah independensi, maka semakin tinggi inflasi. Semakinm rendah tingkat independensi, maka semakin lemah kekuatan bank sentral untuk menolak intervensi pemerintah. Pada situasi ini, bank sentral akan mengikuti kebijakan 


\begin{tabular}{|c|c|c|c|c|}
\hline \multicolumn{5}{|c|}{$\begin{array}{c}\text { Tabel } 2 \\
\text { Hasil Estimasi: Model Engel Granger Error Correction Variabel Dependen: D(PI) }\end{array}$} \\
\hline Variable & Coefficient & Std. Error & t-Statistic & Prob. \\
\hline C & -0.087866 & 0.025741 & -3.413459 & 0.0019 \\
\hline $\mathrm{D}(\mathrm{CBI})$ & -0.784542 & 0.126515 & -6.201202 & 0.0000 \\
\hline $\mathrm{D}(\mathrm{TOR})$ & 0.256597 & 0.192545 & 1.332657 & 0.1927 \\
\hline $\mathrm{D}(\mathrm{LOG}(\mathrm{M} 1))$ & 0.254733 & 0.116107 & 2.193959 & 0.0361 \\
\hline $\mathrm{D}(\mathrm{LOG}(\mathrm{ER}))$ & 0.511670 & 0.051436 & 9.947756 & 0.0000 \\
\hline RESOLS(-1) & -0.366300 & 0.121117 & -3.024357 & 0.0051 \\
\hline R-squared & 0.894532 & \multicolumn{2}{|c|}{ Mean dependent var } & -0.001933 \\
\hline Adjusted R-squared & 0.876954 & \multicolumn{2}{|c|}{ S.D. dependent var } & 0.186933 \\
\hline S.E. of regression & 0.065572 & \multicolumn{2}{|c|}{ Akaike info criterion } & -2.460323 \\
\hline Sum squared resid & 0.128991 & \multicolumn{2}{|l|}{ Schwarz criterion } & -2.196403 \\
\hline Log likelihood & 50.28582 & \multicolumn{2}{|l|}{ F-statistic } & 50.88936 \\
\hline Durbin-Watson stat & 1.970609 & \multicolumn{2}{|l|}{ Prob(F-statistic) } & 0.000000 \\
\hline
\end{tabular}

yang ditetapkan oleh pemerintah. Berdasarkan Sargent dan Wallace $(1981$,$) jika otoritas$ fiskal dominan maka otoritas moneter akan dipaksa untuk untuk bekerja di bawah instruksi pemerintah. Jadi, inflasi akan lebih tinggi karena pemerintah berfokus pada output atau pengangguran. Sebelum Peraturan Tentang Independensi Bank Sentral No 23/1999 diterbitkan, fenomenaini terjadi pada kasus Indonesia.

Sebelum pelaksanaan peraturan ini, Bank Indonesia (BI) praktis bergantung kepada pemerintah secara insititusional. Bank Indonesia memiliki target lain seperti mendorong pertumbuhan ekonomi menurunkan kemiskinan di samping target utamanya yaitu stabilitas harga dan nilai Rupiah. Dengan banyaknya tujuan yang harus dicapai, Bank Indonesia berfungsi sebagai kasir pemerintah atau bagian dari pemerintah, termasuk menjadi agen pembangunan. Dengan fungsi kembar ini, BI menjadi lebih sulit untuk merealisasikan targetnya, sehingga inflasi menjadi begitu tinggi. Contohnya pada periode 1970-1984 rata-rata tingkat inflasi adalah 18 persen setiap tahunnya. Bahkan, pada tahun 1972 dan 1973, tingkat inflasi masing-masing adalah 25.80, 30.63, dan 41.03 persen (IFS, 2008).

Gambar 2 menunjukkan pergerakan inflasi dan tingkat suku bunga dari 1974 hingga 2006. Pada tahun 1970an, tingkat inflasi masih tinggi dan pemerintah mengambil kebijakan moneter yang ketat. Hal ini mengakibatkan penurunan tingkat inflasi di bawah level 1960an tapi tetap di atas 10 persen. Pada tahun 1974, tingkat inflasi adalah 41.03\%, yang dikarenakan oleh banyaknya tujuan yang harus dicapai oleh bank sentral; stabilitas harga dan sebagai agen pembangunan, yang memberikan likuiditas yang tidak terbatas untuk pemerintah. 


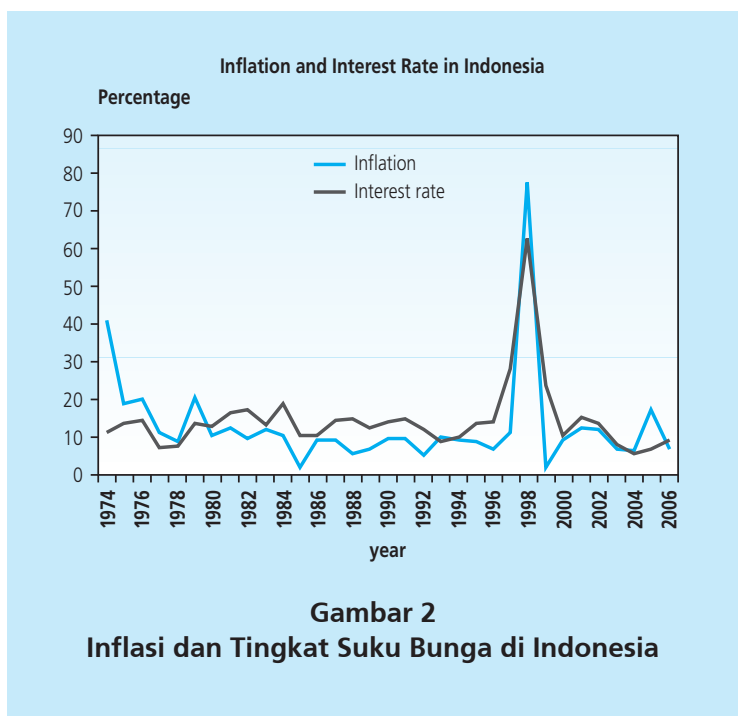

Pada era 1980an kinerja inflasi stabil di bawah 10\% dan tingkat suku bunga dalam kisaran 15 persen. Pencapaian ini diperoleh dari program stabilisasi dan rehabilitasi, diikuti oleh program deregulasi sektor keuangan dan moneter seperti memberikan keleluasaan bagi bank konvensional untuk menentukan tingkat suku bunga mereka sendiri. Pada tahun 1988, pemerintah menerbitkan paket deregulasi yang dikenal sebagai 'Pakto 88', yang memberikan kemudahan bagi pendirian bank baru yang pada akhirnya meningkatkan jumlah bank.

Sebelum tahun 1999, ada beberapa bukti tidak independennya Bank Indonesia. Salah satunya adalah melemahnya kekuatan Bank Indonesia saat pemerintah membentuk dewan moneter, yang meliputi Gubernur Bank Indonesia, Menteri Perdagangan, dan Menteri Keuangan (Raharjo, 2002). Hal ini akan membatasi fleksibilitas Bank Indonesia untuk merumuskan kebijakan moneternya, dan juga merefleksikan independensi dalam merumuskan target. Dalam kerangka ini, Bank Indonesia sebagai otoritas moneter diperbolehkan untuk memiliki berbagai kebijakan moneter; akan tetapi kebijakan yang diterapkan bergantung pada persetujuan pemerintah (Laporan Bank Indonesia, 1966-1984).

Kasus lain adalah pada Oktober 1996 dan April 1997, saat Chief Executive Officer (CEO) dari Bank Indonesia memberikan masukan kepada Presiden Soeharto untuk melikuidasi beberapa bank, dan ditolak (Arismunandar, 2004). Pemerintah menyatakan likuidasi bank-bank tersebut akan menciptakan ketidakstabilan ekonomi dikarenakan permulaan pemilihan umum, dan pada akhirnya Bank Indonesia memberikan dispensasi kepada bank-bank tersebut untuk beroperasi. Satu tahun setelahnya, krisis keuangan Asia terjadi pada tahun 1997.

Selain faktor eksternal, sumber krisis ekonomi 1997 adalah defisit budget pemerintah untuk membiayai hutang luar negerinya. Sebagai bagian dari pemerintah, Bank Indonesia selalu menandatangani setiap kontrak hutang luar negeri (Sitorus, 2007). Jumlah hutang (pinjaman 
resmi dan swasta) meningkat setiap tahun (lihat Tabel 3), dan saat Rupiah terdepresiasi, Indonesia menderita akibat peningkatan nilai hutang luar negeri.

Dampak hutang luar negeri terhadap inflasi sama dengan dampak dari pencetakan uang. Secara teori, pembiayaan defisit melalui hutang luar negeri akan mendorong inflasi dalam jangka panjang, khususnya pada rezim nilai tukar tetap (Harkness, Uriarte 1985; Budina, 2001). Tanpa independensi, Bank Indonesia tidak akan bisa untuk mengendalikan defisit budget pemerintah.

\begin{tabular}{|c|c|c|c|c|c|c|c|c|c|c|}
\hline \multicolumn{11}{|c|}{$\begin{array}{c}\text { Tabel } 3 \\
\text { Komposisi Hutang Indonesia (USS Milyar) }\end{array}$} \\
\hline Year & 1970 & 1980 & 1990 & 1992 & 1993 & 1994 & 1995 & 1996 & 1997 & 1998 \\
\hline Total & - & 20.938 & 69.872 & 88.172 & 89.172 & 107.824 & 124.398 & 128.941 & 136.173 & 150.875 \\
\hline Official & 2487 & 15021 & 47982 & 53664 & 57156 & 63926 & 65309 & 60016 & 55869 & 66944 \\
\hline Private & 461 & 3142 & 10261 & 16281 & 14029 & 24441 & 33123 & 36694 & 44469 & 54728 \\
\hline
\end{tabular}

Melalui peraturan No. 23/1999, Bank Indonesia memiliki independensinya. Dengan peraturan ini, penunjukan dan pemberhentian pejabat eksekutif bank sentral diputuskan oleh dewan gubernur bank sentral. Dengan peraturan ini, Bank Indonesia dilarang untuk membeli sekuritas pemerintah pada pasar primer untuk menghindari peningkatan uang beredar. Selain itu, peraturan ini juga menjamin independensi Bank Indonesia dalam penentuan satu target, yaitu stabilitas harga.

Setelah legalitas independensi ini, tingkat inflasi berkurang. Bank Indonesia menggunakan kebijakan moneter yang ketat dan berhasil mengurangi tingkat inflasi dari 77.63 persen pada tahun 1998 menjadi 2.1 persen pada tahun 1999. Rata-rata inflasi berkisar 8 persen dari 1989 hingga 2004. Pada tahun 2005, ekonomi mengalami inflasi yang tinggi (17.11 persen), dikarenakan peningkatan harga minyak. Ini merupakan inflasi tertinggi selama periode pasca krisis 1997/1998. Pada tahun 2006 Bank Indonesia menerapkan Inflation Targeting Framework (ITF), dan berhasil mengurangi inflasi mendekati target yang telah ditetapkan sebesar 6 persen dan nilai tukar menjadi Rp. 8500 per USD. Meskipun demikian, tingkat inflasi ini masih lebih tinggi dibandingkan negara-negara berkembang lainnya seperti Malaysia dan Thailand yang berkisar 2 persen.

Banyak usaha telah dilakukan Bank Indonesia untuk melakukan penerapan kebijakan yang lebih baik. Pertama adalah mengganti pengeluaran pemerintah dari non-anggaran ke sisi anggaran. Yang kedua adalah memasukkan subsidi suku bunga untuk kredit likuiditas ke dalam budget pemerintah (Djiwandono, 2001). Langkah ketiga adalah melakukan intervensi pada pasar mata uang asing untuk menjaga stabilitas Rupiah, sebagaimana juga dilakukan oleh 
Monetary Authority of Singapore (MAS) dan Government of Singapore Investment Corporation (GSIC). Hasilnya adalah apresiasi Rupiah (Achjar, 2001).

Ukuran kedua dari independensi bank sentral adalah pergantian gubernur. Seperti yang telah disebutkan sebelumnya, koefisien pergantian bank sentral (TOR) secara statistik tidak signifikan, yang berarti kontradiktif dari hipotesis awal, meski memiliki arah yang benar (tanda positif). Umumnya, makin tinggi frekuensi pergantian gubernur bank sentral, makin rendah tingkat independensi dan akan semakin tinggi inflasi (Cukierman, Webb, dan Neyapty, 1995). Korelasi positif antara TOR dan inflasi terjadi karena ketidakstabilan politik juga berdampak kepada ketidakstabilan bank sentral, karena pemilihan gubernur bank sentral dipengaruhi oleh transisi politik. Indikator TOR cenderung relatif stabil sebelum krisis 1997 . Siklus pemilihan setiap 5 tahun untuk bank sentral sama dengan siklus pemilihan pemerintah. Selama proses transisi (reformation, 1998-1999), posisi gubernur bank sentral merupakan perhatian utama dari partai politik; seperti saat Soeharto digantikan oleh B.J. Habibie, di waktu yang sama J. Soedradjad Djiwandono juga digantikan oleh Syahril Sabirin (Sabirin, 2008).

Perlu ditegaskan bahwa meskipun independensi bank sentral ada karena peraturan hukum, Bank Indonesia membutuhkan independensi de-facto. Salah satu contohnya adalah intervensi pemerintah yang dibuat oleh Abdurrahman Wahid (Presiden Indonesia keempat) dengan mengganti gubernur Bank Indonesia yang terpilih Syahril Sabirin pada tahun 2000. Intervensi seperti itu akan menyebabkan ketidakstabilan politik dan melemahkan mata uang Indonesia. Periode pemerintahan 5 tahun terlalu pendek bagi bank sentral untuk merumuskan kebijakan jangka panjang untuk mewujudkan stabilitas harga (Panagiotidis, 2005). Pilihan yang paling memungkinkan untuk Indonesia adalah melaksanakan pemilihan gubernur tiap 10 tahun seperti pada Federal Reserve di Amerika Serikat dan pada Deutsche Bundesbank di Jerman yang melakukan pemilihan setiap 7 tahun.

Seperti yang disajikan pada Tabel 2, model Engel Granger Error Correction mengkonfirmasi hubungan jangka panjang antar inflasi, nilai tukar, uang beredar, dan independensi bank sentral. Kecepatan penyesuaian koefisien adalah 0.37, menunjukkan cepatnya koreksi untuk deviasi inflasi terhadap keseimbangan jangka panjang. Sebagaimana model standar, model Engel Granger ECM juga menunjukkan bahwa indeks legal CBI berdampak terbalik pada inflasi, sementara TOR berpengaruh positif namun tidak signifikan. Perubahan jangka pendek pada kedua variabel kontrol juga signifikan dalam mempengaruhi inflasi; peningkatan jangka pendek pada uang beredar akan meningkatkan inflasi secara signifikan, sedangkan depresiasi Rupiah jangka pendekakan meningkatkan inflasi.

Walaupun hasil dari model yang diestimasi berbeda dari beberapa temuan umum pada negara-negara berkembang, namun kita dapat menemukan hasil yang sama pada Yunani, di mana CBI legal berkorelasi negatif dan signifikan terhadap inflasi, (Panagiotidis, 2005). la juga menemukan bahwa TOR juga berkorelasi positif terhadap inflasi dengan tingkat signifikansi yang lebih rendah. 


\section{KESIMPULAN}

Penelitian ini menganalisis hubungan antara Independensi Bank Sentral (CBI) dan inflasi di Indonesia dengan menggunakan dua indikator; indeks CBI legal dan pergantian gubernur bank sentral (TOR). Kesimpulan pada studi ini adalah independensi bank sentral memiliki pengaruh terbalik terhadap inflasi. Implikasi temuan ini jelas bagi Bank Indonesia yakni memperkuat independensinya, untuk memudahkan pencapaitan target inflasi yang rendah.

Terdapat beberapa keterbatasan pada studi ini; pertama, perlu untuk internalisasi Peraturan Independensi Bank Sentral No. 23, 1993, langsung ke dalam model dan menemukan bagaimana penerapan kebijakan ini berdampak kepada pengaruh CBI terhadap inflasi; kedua, berhubungan dengan teknik estimasi, perlu untuk menggunakan metode lain seperti model Wickens-Breusch, yang dipercaya dapat bekerja lebih baik. 


\section{REFERENSI}

Ahsan, 2006. 'Central Bank Independence \& Governance (CBIG) and Inflation in Asia Pacific'.

Ahsan, 2006. 'Determinants of central bank independence and governance: Problems and policy implications', JOAAG,, Vol. 1 (No. 1).

Annonynomous 1996, 'Angka Inflasi di Zaman Orla dan Orba ', Kompas Online http://www. kompas.com/9609/07/EKONOMl/angk.htm.

Arismunandar 2004, 'Refleksi 50 Tahun Bank Indonesia: Menuju Independensi Demi Pencapaian Misi dan Visi (Reflection of 50 Years of The Bank of Indonesian: Independence in Pursuing Vision and Mision)'.

Bade and Parkin, 1988. 'Central Bank Laws and Monetary Policy'. Department of Economics, University of Western Ontario, Mimeo.

Barro and Gordon, 1983. 'A Positive Theory of Monetary Policy in a Natural Rate Model', Journal of Political Economy, Vol. 91, No. 4, Aug.

Barro and Gordon, 1984. Rules, Discretion and Reputation in a Model of Monetary Policy, "NBER Working Papers (1070).

Berger, 2000. ' 'Central Bank Independence: An Update of Theory and Evidence'. CESifo Working Paper Series, No. 255.

Berger, Haan and Eijffinger, 2001. 'Central Bank Independence: An Update of Theory and Evidence', Journal of Economic Survey, Vol. 15(1), pages 3-40,

Budina, 2001. ' Inflation Stabilization, Fiscal Deficits, and Public Debt. Journal of Economic Literature. E63, F34, E52, E41

Brumm, 2002. 'Inflation and Central Bank independence revisited', Economics Letters, 77 (205-209).

Campilo and Miron, 1996. 'Why Does Inflation Differ Across Countries', Working PAper 5540.

Cukierman, 1992. 'Measuring the Independence of Central Banks and Its Effect on Policy Outcomes', The World Bank Economic Review, Vol. 6. No. 1: 35J-J9J.

Cukierman, 1995. 'Measuring the Independence of Central Banks and Its Effect on Policy Outcomes', The World Bank Economic Review., Vol. 6. (No. 1: 35J-J9J). 
Cukierman, 2006. 'Central Bank Independence and Monetary Policymaking Institutions - Past Present and Future', Central Bank of Chile Working Paper, (360).

Eijffinger, 1997. 'The New Political Economy of Central Banking', Center for Economic Research,.

Eijffinger, 1998. ' Central Bank Independence: A Sensitivity Analysis, " European Journal of Political Economy, Elsevier, vol. 14(1), page 73 - 88, February.

Fransisco, 2003. 'Time-Inconsistent Monetary Policies: Recent Research', FRBSF Economic Literature

Grilli at al, 1991. ' Political and Monetary Institutions and Public Financial Policies in the Industrial Countries, Economic Policy, 13, pp. 341-392.

Guerrero, 2007. 'Japan's Deflation: A Time-Inconsistent Policy in Need of an Inflation Target', Journal compilation.

Hafild, 2000. 'Addicted to Loan: The World Bank Foot Prints in Indonesia', Briefing Paper

Hayo and Voigt 2005, ' Inflation, Central Bank Independence and the Legal System'. Journal of Economic Letter.

Hicks, 2004. 'Does Institutional Change Matter? The effect of central bank reform on inflation', Paper presented at the annual meeting of the The Midwest Political Science Association, Palmer House Hilton, Chicago, Illinois.

Hutabarat, 2005. 'The Determinant of Inflation', Occasional Paper No. 06.

Ilyas, Achjar 2001."Independensi Bank Indonesia Menuntut Akuntabilitas yang Tinggi".

'Indonesia: Economic and Social Update November 2007', 2007.

Ismihan, 2004. 'Does Central Bank Independence Lower Inflation?', Economics Letters, 84 (3).

Jacome, 2007. 'Is there Link Between Legal Central Bank Independence and Inflation?Evidence from Latin America and Caribbean'. European Journal of Political Economy.

de Jong. E 2002. 'Why are Price Stability and Statutory Independence of Central Banks Negatively Correlated? The Role of Culture. European Journal of Political Economy, 18, 675 - 694.

Juhro, 2007. 'Karakteristic Tekanan Inflasi di Indonesia: Pengaruh Dinamis Sisi PermintaanPenawaran dan Prospek ke Depan (Characteristic of Inflationary Pressure in Indonesia: Demand - Supply Side Dynamic Effect in Advance)'.

Lohmann, S. (1992). The optimal commitment in monetary policy: credibility versus flexibility, in "American Economic Review", 82, March, 273-286. 
Lonnberg, 2008. 'Issues in Central Bank Finance and Independence', Working Paper 13.

Luis I. J'acome H., 2007. 'Is there any link between legal central bank independence and inflation? Evidence from Latin America and the Caribbean', European Journal of Political Economy.

Luna, 2003. 'Central Bank Independence and Price Stability: Evidence from 23 OECD-countries', Oxford Economic Papers, 60: 410-422

Murray, 2008. ' Measuring inflation - methodology and misconceptions'.

Panagiotidis, 2005. 'Central Bank Independence and Inflation: the Case of Greece. Journal of Economic Letter. E.58, E. 52.

Pollard, 1993. 'Central Bank Independence and Economic Performance', Economics Papers, (21-36).

Prescott, 1977. 'Rules Rather than Discretion: The Inconsistency of Optimal Plans', The Journal of Political Economy, Vol. 85, (No. 3, pp. 473-492).

Rahardjo, 2000. 'Independensi Bank Indonesia dalam Kemelut Politik (Bank Indonesia's Independence in Political Turbulence)'.

Restepo, 2000. 'Central Bank Independence and Inflation: The Case of Colombia, 1924$1998^{\prime}$.

Rissal, 2000. 'Independensi dan tuntutan transformasi Bank Indonesia'.

Rogoff, 1985. ' The Optimal Degree of Commitment to an Intermediate Monetary Target Author(s). The Quarterly Journal of Economics, Vol. 100, No. 4 (Nov., 1985), pp. 1169-1189 Published by: The MIT Press

Sabirin, S, 2008. 'Pejuang Independensi Bank'. The Hero of Central Bank Independence Indonesia'.http://www.tokohindonesia.com/ensiklopedi/s/syahril-sabirin/index.shtml

Samiei, 1999. 'Central Bank Independence and Conduct of Monetary Policy in United Kingdom', IMF Working Paper.

Summers, 1993. 'Central Bank Independence and Macroeconomic Performance: Some Comparative Evidence', Journal of Money, Credit and Banking,, Vol. 25, (No. 2, pp. 151162).

Swasono, 2000. 'Independensi Bank Indonesia Yang Terbukti Runyam (The difficulty of Indonesian Central Bank)'.

Tambakis, 1999. 'Effective Central Bank Independence and the Inflation-Output Trade-Off', Journal of Macroeconomics, Vol. 21 ( No. 4, pp. 729-753).

The Bank of Indonesia, 2008." The Historical of The Bank of Indonesia (1966-1983)

The Bank of Indonesia, 2008." The Historical of The Bank of Indonesia (1983-1997) 
The Bank of Indonesia, 2008." The Historical of The Bank of Indonesia (1997-1999)

The Bank of Indonesia, 2008." The Historical of The Bank of Indonesia (1953-1959)

The Bank of Indonesia, 2008." The Historical of The Bank of Indonesia (1999-2005)

Triampella, 2005. 'Central Bank Independence and Inflation: the Case of Greece', Discussion Paper Series, (7).

Uriarte, 1985. 'Transnational Banks, and the Dynamics of Peruvian Foreign Debt and Inflation.'.

Vázquez, 2005. 'Any Link Between Legal Central Bank Independence and Inflation? Evidence from Latin America and the Caribbean', IMF Working Paper.

Voigt, 2005. 'Inflation, Central Bank Independence and the Legal System', ICER Working Papers, (2).

Walsh, 1995. 'Optimal Contracts for Central Bankers', American Economic Review.

Walsh, 2003. 'Monetary Theory and Policy (Second Edition), Cambridge US and London UK: The MIT Press,

Waud, 1995. 'Central Bank Independence and the Output-Inflation tradeoff'. Journal of Economics and Business, Elsevier, Vol. 47(2), page 137-149, May.

Webb, 1995. 'Political Influence on the Central Bank: International Evidence', The World Bank Economic Review, VOL. 9, (NO. 3 ): 397-423. 